\title{
Substantial Dose-response Relationship with Clinical Outcome for Lung Stereotactic Body Radiotherapy (SBRT) Delivered via Online Image Guidance
}

L. Kestin

William Beaumont Hospital

I. Grills

William Beaumont Hospital

M. Guckenberger

University of Wuerzburg

J. Belderbos

Netherlands Cancer Institute Follow this and additional works at: https://jdc.jefferson.edu/bodinejournal

\section{Ree nextpage for additional authors}

Kestin, L.; Grills, I.; Guckenberger, M.; Belderbos, J.; Hope, A. J.; Werner-Wasik, M.; Sonke, J. J.;

Bissonnette, J. P.; Xiao, Y.; and Yan, D. (2010) "Substantial Dose-response Relationship with Clinical Outcome for Lung Stereotactic Body Radiotherapy (SBRT) Delivered via Online Image Guidance," Bodine Journal: Vol. 3 : Iss. 1 , Article 34.

DOI: https://doi.org/10.29046/TBJ.003.1.033

Available at: https://jdc.jefferson.edu/bodinejournal/vol3/iss1/34

This Article is brought to you for free and open access by the Jefferson Digital Commons. The Jefferson Digital Commons is a service of Thomas Jefferson University's Center for Teaching and Learning (CTL). The Commons is a showcase for Jefferson books and journals, peer-reviewed scholarly publications, unique historical collections from the University archives, and teaching tools. The Jefferson Digital Commons allows researchers and interested readers anywhere in the world to learn about and keep up to date with Jefferson scholarship. This article has been accepted for inclusion in Bodine Journal by an authorized administrator of the Jefferson Digital Commons. For more information, please contact: JeffersonDigitalCommons@jefferson.edu. 
Substantial Dose-response Relationship with Clinical Outcome for Lung Stereotactic Body Radiotherapy (SBRT) Delivered via Online Image Guidance

Authors

L. Kestin, I. Grills, M. Guckenberger, J. Belderbos, A. J. Hope, M. Werner-Wasik, J. J. Sonke, J. P. Bissonnette, Y. Xiao, and D. Yan 


\section{Substantial Dose-response Relationship with Clinical Outcome for Lung Stereotactic Body Radiotherapy (SBRT) Delivered via Online Image Guidance}

Kestin, L., ${ }^{1}$ Grills, I., ${ }^{1}$ Guckenberger, M., ${ }^{2}$ Belderbos, J., ${ }^{3}$ Hope, A.J., ${ }^{4}$ Werner-Wasik, M., ${ }^{5}$ Sonke, J-J., ${ }^{3}$ Bissonnette, J-P., ${ }^{3}$ Xiao, Y., ${ }^{5}$ Yan, D. ${ }^{1}$

${ }^{1}$ William Beaumont Hospital, Royal Oak, Ml

2University of Wuerzburg, Wuerzburg, Germany

${ }^{3}$ Netherlands Cancer Institute, Amsterdam, Netherlands

${ }^{4}$ Princess Margaret Hospital and University of Toronto, Toronto, ON

${ }^{5}$ Department of Radiation Oncology, Thomas Jefferson University and Hospitals, Philadelphia, PA

\section{Purpose}

To examine potential tumor dose-response relationships with various non-small cell lung cancer (NSCLC) SBRT fractionation regimens delivered with online CT-based image guidance.

\section{Materials/Methods}

Four-hundred-four (404) tumors in 382 patients with clinical stage T1-T2 N0 NSCLC were treated with CT-based (Elekta cone-beam CT) online image-guided SBRT at 5 institutions (1998-2009) and had available 3D dose-volume data for the gross tumor volume (GTV) and planning target volume (PTV). All cases were planned with heterogeneity correction. Median maximum tumor dimension was $2.4 \mathrm{~cm}$ (range $0.9-7.3 \mathrm{~cm}$ ). Dose fractionation prescription was according to each institution's protocol with the most common schedules of 18-20 Gy x 3, 12 Gy x 4, 12 Gy x 5, 12.5 Gy x 3, 7.5 Gy x 8 (median=54 Gy, 3 fractions). Median prescription $(\mathrm{Rx}) \mathrm{BED}_{10}=132$ Gy (60-180). Median values (Gy) of 3D planned doses for $\mathrm{BED}_{10}$ were GTVmin=165, GTVmean=190, GTVmax=207, PTVmin=115, PTV D99=116, PTVmean=166, PTV D1=199, PTVmax=207. Mean follow-up=1.3 years.

\section{Results}

Twenty-two (22) cases (5\%) had local recurrence (LR) for a 2-year rate of 9\%. All $\mathrm{BED}_{10}$ GTV \& PTV endpoints were significantly associated with LR $(\mathrm{p}<0.01)$ as continuous variables on univariate analysis. PTV mean dose appeared to have the highest correlation with LR with area under ROC curve of $0.74(\mathrm{p}<0.01)$ and an optimal cut point of $125 \mathrm{~Gy} \mathrm{BED}_{10}$. Two-year LR was $4 \%$ for PTVmean $>125$ vs $30 \%$ for $<125$ Gy $(\mathrm{p}<0.01)$ with sensitivity $=87 \%$ and specificity $=59 \%$ for predicting LR. Two-year LR for $\mathrm{Rx} \mathrm{BED}_{10}>105$ was $5 \%$ vs $19 \%$ for $<105 \mathrm{~Gy}$ ( $\left.\mathrm{p}<0.01\right)$. GTV size was associated with LR on univariate analysis as a continuous variable ( $\mathrm{p}=0.05$ ) with 2 -year LR of $5 \%$ for $<2.7 \mathrm{~cm}$ vs $12 \%$ for $\geq 2.7 \mathrm{~cm}(\mathrm{p}=0.01)$.
PTVmean $\mathrm{BED}_{10}(\mathrm{p}<0.01)$ and GTV size $(\mathrm{p}=0.04)$ were independent predictors on multivariate analysis as continuous variables. PTVmean $\mathrm{BED}_{10}$ was also associated with distant metastasis on univariate and multivariate analysis, but not overall survival.

\section{Conclusion}

There are clear dose-response and tumor volume-response relationships for local control of NSCLC following image-guided SBRT with possible optimal PTVmean $\mathrm{BED}_{10}$ of $>125 \mathrm{~Gy}$ in this dataset. 